\title{
JUDI DENCH AND SHAKESPEAREAN PERSONAS IN THE TWENTY-FIRST CENTURY
}

\author{
SOPHIE DUNCAN
}

\begin{abstract}
Dame Judi Dench's twenty-first-century theatrical career has defied the expectation that her performance as the Countess in the Royal Shakespeare Company's 2003 All's Well That Ends Well would signal the culmination and conclusion of her stage acting career. This article draws on scholarship on the use of retrospection and persona-building to redirect attention from Dench's conspicuously 'late' success in film to map how Dench has led, collaborated in and resisted public constructions of her persona. Shakespeare has been consistently key to this process. While enlisting persona-building strategies inherited from her Shakespearean forebears, Dench has resisted the overt appointment of any kind of Shakespearean 'successor' and thus the continuation of Shakespeare performance genealogies. Simultaneously, her role choices have contributed to her persona's accrued significance as an avatar of moral virtue and authenticity - augmented by her association with the 'national poet', Shakespeare, as England's most prestigious playwright. The article also examines Dench's persona specifically as an ageing actress, and her significance for discourses of aspirational ageing, ageism, and national investments in the ageing female performer as a public persona.
\end{abstract}

\section{KEY WORDS}

Shakespearean Roles; Celebrity; Ageing; Silence; Moral Authority; Nation

\section{INTRODUCTION}

Commentary on Dame Judi Dench (b. 1934) typically emphasises her unusual career trajectory. Dench has been an acclaimed classical stage actress since the 1960s, achieving international stardom as an older performer following film success in the late 1990s. Dench attained international film recognition via lightly revisionist accounts of British queens: the widowed Victoria with unconsummated yearnings (Mrs Brown, 1997, returned to in Victoria and Abdul, 2017) and a sharp-tongued, sexually astute but still-virginal Elizabeth I (Shakespeare In Love, 1998). Dench appeared eight times in another British institution, the James Bond franchise, as the first female M. M's death in Skyfall (2015) was perhaps Dench's most shocking cinematic demise, but not unique; Iris Murdoch's slow decline in Iris (2001) won Dench a BAFTA and an Oscar nomination. She has played occasional villains (Notes on a Scandal, 2006) and victims (Philomena, 2013), but on film typically explores the professional, intellectual, and/or romantic vitality of "slightly sad" older women (Bradshaw 2019), as in Tea With Mussolini (1999), Mrs Henderson Presents (2005), and the two Best Exotic Marigold Hotel films (2011 and 2015). While occasional critics detect a sexist and ageist trajectory for Dench's M "from Iron Lady to old lady" 
(Pua 2018, p. 95), popular and scholarly consensus is usually that Dench's "unique trajectory [...] fabulously subverts [...] the general tendency for bias" against "older actresses" (Krainitzki 2014, p. 32) while offering a glamorous, "graceful negotiation of ageing" (Williams 2015, p. 161). For colleague Dearbhla Molloy, one of Dench's "greatest gifts [...] is her modelling of how to grow old with dignity" (Molloy 2005, p. 98). Accounts of Dench's film work emphasise the "lateness" of her success: however, if Dench was not expected to have a twenty-first century film career, neither was she expected to have one in theatre. Michael Dobson identified Dench's 2003 Countess in All's Well That Ends Well as essentially her swansong, describing the "consciousness in all our minds that [...] this would almost certainly be the last Shakespearian [sic] role Dame Judi would ever play on stage" (Dobson 2005, p. 163) in "one of those occasions of national mourning which the English do so well, partaking slightly of the mood of the Queen Mother's funeral" (p. 164). Misidentifying the positively last appearance is a hazard of commenting on older stars. In May 2018, Caitlin Moran responded to a CNN commentator's description of Prince Harry's marriage to Meghan Markle as "a poignant occasion for the Queen - as this must be her last wedding" with patriotic outrage: "Hang on! Princess Eugenie is getting married in October! [...] Long live Her Majesty, you mad American bastards! We reckon we can keep her alive for a good while yet!" (Moran 2018). Dench is, if anything, more beloved than the Queen, with an 81\% approval rating vs. the Queen's 72\%; both are idealised elderly female figureheads with their strongest fanbases among middle-aged women (YouGov 2018a \& $2018 \mathrm{~b}$ ). England's establishment culture is predicated on astonished celebration of female longevity, and fear of its curtailment.

Examining the "late voice" of late-career musicians, Richard Elliott identifies "the retrospection allowed [to performers] by lateness and successful ageing"; this article argues that Dench's conspicuously "successful ageing" has allowed her to use retrospection to control and shift her public personas (Elliott 2019, p.19). Elliott also examines how musicians active across multiple decades often accrue two kinds of diametrically opposed attributed personas: the "artist as shape-shifter" and the "artist as consistent, layered self" (p. 20). While Elliott primarily locates his concept of "autobiographical performance" (p. 19) in the performance of original songs by their songwriters, I argue that Dench has made crucial use of Shakespearean roles to build and sustain her twenty-first century personas. The roles Dench has played carry connotations of virtue, truthfulness and authenticity which have (in Marvin Carlson's terminology) "ghosted" the actress and contributed to her construction as an individual whose performances of truthfulness and authenticity are "consistent" with her offstage self. Elliott positions the star musician as "constructing his personas in collaboration with the readerproducers who are his audience" (Elliott 2019, p. 19): in considering Dench's attributed persona of virtue and authenticity, and the equally powerful narrative of her as ideally loveable friend and national treasure, I extend this paradigm to present Dench "constructing her personas in collaboration" and occasional conflict "with the reader-producers" who include both her audiences and her colleagues.

In performance, Dench is rarely conceptualised as a "shape-shifter". David Hare notes that audiences "trust who [Dench] is" (Hare 2005, p. 180). Dench is typically visually and audibly recognisable in her roles, eschewing prosthetics and rarely forsaking her own Received Pronunciation accent; at the time of writing, the trailer for the Cats film sees Dench, cross-cast as Old Deuteronomy, forswearing the (alarming) CGI and heavier make-up of her co-stars, and speaking in her own voice. Dench's intense reluctance to discuss her performance technique, or even to admit she has one, elides any distinction between her on- and offstage presence, implying a "consistent [...] self" and reifying Hare's claim. Richard Eyre argues that she has "technique to burn [...] but her technique never shows" (Eyre 2005 p. 41), while critics delineate a very sophisticated vocal technique (Prince 2013): moreover, Dench (alongside other Royal Shakespeare Company colleagues) worked with director John Barton on a series of live and televised demonstrations of classical acting techniques. Dench's reception stresses her stylistic emphases on vulnerability, emotional openness, and the vocal immanence of distress with a 
"bluesy alto" that "can bend a note from joy to sob" (Eyre 2005 p. 41), reflected in the title of Miller's 2005 biography, With A Crack In Her Voice. Moreover, ongoing emphasis (by Dench and others) on her diminutive and supposedly plain appearance (as discussed below) is also key to her persona. At the same time, if Dench's physical "shape" and performance style have been consistent, in one respect she has been a "shape-shifter". Before, during, and after her marriage to actor Michael Williams, Dench's constructions of her personal life have shifted considerably. While many celebrities deploy silence as a strategy to conceal difficult aspects of their personal lives, Dench's retrospectives on her personal life use silence to displace both family and colleagues' disruptive accounts of her persona, and her own earlier frankness about her sexuality and temper. By contrast, performing Shakespeare's Countess of Rousillon enabled "autobiographical performance" as Dench constructed her new persona as a widow, reinscribing her attributed persona of honesty and authenticity.

\section{SHAKESPEAREAN PERSONAS}

Since playing Countess of Roussillon, Dench has performed in six further stage productions, half of them Shakespearean: as Judith Bliss in Hay Fever (Haymarket, 2006); Mistress Quickly in The Merry Wives of Windsor (RSC, 2006); the Marquise in Madame de Sade (Wyndham's, 2009); Titania in A Midsummer Night's Dream (The Rose, 2010); Alice in Peter and Alice (Noel Coward, 2013); Mother in The Vote (Donmar, 2015); and Paulina in The Winter's Tale (Garrick, 2015). She has performed further scenes from Shakespeare in televised galas: as Cleopatra in National Theatre Live: 50 Years on Stage (2013) and as Titania and (very briefly) Hamlet in Shakespeare Live! From the RSC (2016). Dench has also played an additional filmed Shakespeare role: the Duchess of York in Richard III (BBC, 2016).

Dench has repeatedly chosen roles which reinforce the ascription of honesty and virtue which colleagues identify as key to both her public persona and personal qualities. She plays women intent on moral justice, whether in Paulina's confrontation of the deluded Leontes, or as Mishima's Marquise, clinging to order as both her daughters succumb to the Marquis de Sade. The assistant director's rehearsal script for All's Well consistently glosses Dench's characterisation in terms of a passion for truth: the Countess wants Helena to "cut the crap" and "calls H[elena's] self deception" in Act 1, Scene 3 (RSC 2003). These notes stress the character's obsession with "flushing" out honesty to a degree unusual in the play's performance history (RSC 2003). The Countess offers a prototype for Dench's "truth-telling Paulina", reviewed by Billington as almost Christ-like in her "deep compassion for wayward humanity" (Billington 2015). As Benedict Nightingale notes, stage audiences have "never seen her embody evil"; she refused to play Brutus on the grounds that she could not "believe in an absolute or motiveless evil", and reportedly "hated playing Regan", finding "inexplicable [...] the sheer awfulness of Lear's most callous daughter" and, in Hamlet, Gertrude's behaviour "egregious" (Nightingale 2005, p. 15). In disclaiming or disliking these roles, Dench is adopting a persona both rooted in historical practice and contiguous with the construction of Elliott's "consistent [...] self". Shakespearean actresses have recognised the value of moral roles in successful personabuilding for over a century: as Madge Kendal (1847-1935) put it, audiences want to believe that "when the curtain has fallen", the performers "at home [...] lea[d] [...] the same kind of life the representation of which has moved an audience" (Kendal 1884, p. 23), an impulse far less satisfactorily fulfilled by Gertrude and Regan than by Paulina or the Countess.

The longevity and public happiness of Dench's marriage to actor Michael Williams, supported and perhaps also cued this elision of on- and offstage personas: like Kendal, Dench frequently acted opposite her husband in romantic comedy roles, presenting their onstage (and in Dench and William's cases, onscreen) partnerships as an avatar of their private relationship. This emphasis on domesticity was almost as attractive to twentieth-century audiences as to their eighteenth and nineteenth-century forebears, provoking a journalistic emphasis on Dench's "domesticity" that inherited from the 1784 adulation of Sarah Siddons as one who 
"dignifies her state in PRIVATE sphere" as "WIFE unblemished and the MOTHER dear" (qtd McDonald 2005, p. 10). Dench's collusion in ideal narratives about her life draws on paradigms inherited not just from Kendal but from other nineteenth- and twentieth-century actresses such as Ellen Terry (1847-1928). Dench has been repeatedly named as Terry's "natural successor" (McDonald 2005, p. 52), both in her uxorious interpretation of Lady Macbeth (Nightingale 2005, p. 16) and for being "in public perceptions" comparably "loved and revered" (Sherrin 2005, p. 137). More recently, Dench delightedly announced a newly-discovered ancestor in the actress Sarah Siddons (McDonald 2005, p. 104). Dench's biographer John Miller also stresses her link with Mary Anderson (1859-1940), "the only other actress to have doubled Hermione and Perdita [in The Winter's Tale]" who "was also married at the very same church during the run of The Winter's Tale" as Dench and her husband Michael Williams during Dench's own run in 1971 (Miller 2013, p. 122).

\section{ATtRIBUted PERsonAs}

Critic Michael Billington describes Dench as trying to offer audiences "spiritual solace" (Billington 2005). Accounts of her virtue are hyperbolic: actor Ian Richardson felt she had "no faults, either personally or professionally" (Richardson 2005, p. 32). She is also mysticised as one who "make[s] visible the Divine [...] she manifests love" with "her brow kissed by God" (Molloy 2005, p. 92), blessed because "[t]he Gods of the theatre look after those who serve them well" (Edmonds 2003, p. 14), and able to "emanate a spirit of something very good" (Connolly 2005, p. 174). Dench's prominence as a Quaker, reflected in Smith's glossing of her amenability as "the Quaker [...] com[ing] out", is important here, but Dench's own discussion of her faith rests (perhaps predictably) more on the introspection, silence and stillness than on Quakerism's history of political dissent (as I will discuss later). Dench describes her religion as both "real, Christian faith", and more prosaically "very quiet, which is what I am not [...] time to get all the drawers organised inside my head" (Appleyard 2013). In fact, the religious rituals Dench has (anecdotally) undertaken tend towards her late husband's Catholicism: Dench and Michael Williams, alongside Catholic actress Dearbhla Molloy, undertook weekly fasts "for the best part of a year", to coincide with operations on Molloy's sister (Molloy 2005, pp. 90-1). As Marvin Carlson notes, performers and characters can accrue, or become "ghosted" by, reciprocal meanings (Carlson 2003, pp. 52, 58, 103): accordingly, Benedict Nightingale describes Dench as possessing "as much moral authority as any actor or actress in the world [...] a moral centredness or a spiritual integrity" (Nightingale 2005, p. 18). Crucial to understanding Dench's reception is Michael Pennington's description of her as "among the very few with that perceptible moral authority, the implicit virtue the public seeks from artists" (Pennington 2005, p. 65). Pennington's use of "artists" is gender-neutral, but the "implicit virtue" is implicitly gendered: the public rarely "seeks" or expects virtue from male performers or artists. Certainly, the desire to locate "moral authority" in Dench reflects the manner in which declining theatre subsidies require theatres to justify their funding via their catalytic power as a "force for good": at the same time, public faith in the "truth-telling" of other institutions has ebbed (BSA 2018). Paulina's determination to "trumpet" her "red-look'd anger" at Leontes' "tyranny" (II.2.33-4; II.3.119) is a metaphor for the relation theatre is expected to have to power. Nevertheless, British culture continues to fetishise the virtuous actress. Dench's "implicit virtue" transcends any lingering anti-theatrical prejudice against the actress as immoral (i.e. unchaste). Moreover, Dench's "moral authority" also counteracts the most troubling stereotype specifically of the older actress: the difficult, vain, deluded Norma Desmond figure, whose rapacity includes sexual predation.

Instead, colleagues and the press attribute almost hyperbolic amiability and virtue to Dench. This persona is sufficiently entrenched to generate parody: comedian Tracey Ullman performs a recurring sketch in which a cackling Dench evades punishment for nefarious crimes simply because nobody can believe she's a felon ("Dame Judi Dench causes havoc" 2016). Similarly, Dench's colleague, friend, and peer Dame Maggie Smith (whose international fame is, 
if anything, greater following the Harry Potter and Downton Abbey franchises) wryly contrasted her famed "prickliness" with Dench's equally famous amenability, describing how she begins each job with the vow to "be like Jude [...] it will all be lovely, it will be merry and bright, the Quaker will come out in me" but "it never works" (Calkin 2015). Other friends are hyperbolic: Dench "makes time for everyone" (Piggott-Smith 2005, p. 135), is "generous and progressive" (Pennington 2005, p. 64), both "radiates" and "manifests" love (Molloy 2005, p. 97). She is a "generous, easy-going and gifted" colleague (Guittard 2005, p. 152), who evinces "bravery and sheer guts" (Leigh-Hunt 2005, p. 26), "compassion" and "good manners" (Eyre 2005, pp. 36-7). Stanley Wells, her daughter's godfather, wrote that describing her inevitably becomes a "love letter" (Wells 2005, p. 57); Ian Richardson felt she had "no faults, either personally or professionally" (Richardson 2005, p. 32), and her biographer John Miller describes "her ready sympathy, her alert sensitivity to the problems of others, her quick intelligence, her bubbling sense of humour, her astonishing generosity and thoughtfulness" (Miller 2005, p. 1). Dench's popularity is such that playwright Alan Bennett claimed that Britain's most unacceptable t-shirt slogan would be "I HATE JUDI DENCH" (Eyre 2005, p. 35). From younger actors, such hagiographies could (understandably) be attributed to a desire to accrue professional capital through alliance with Dench: while Molloy (as I discuss later), certainly self-fashions as Dench's successor, this hardly applies to the actors above. What does emerge, however, is the desire to present the private Dench as contiguous with her persona, exemplified by Miller's answer to the supposedly perennial question re: Dench, "Is she really as nice as she seems?" that she is "even nicer when you get to know her" (2005, p. 1), a remark that both invites audiences' parasocial desire for greater intimacy with Dench, and - simultaneously - assures them that they are able to "trust who she is".

\section{PhysicAl APPEARANCE AND PERSONA}

If Dench's visual and stylistic consistency, her "recognisability" has earned her praise for her authenticity as a "consistent, layered self" (Elliott 2019, p. 19) rather than a transformative and shapeshifting artist, her specific aesthetic of ostensible "ordinariness" has been vital to her midand late-career persona. Dench's supposed physical "ordinariness" is also key to her persona: a mythopoeia of anti-glamour in which Dench recounts being told by "a [nameless] Hollywood producer" that she "had every single thing wrong with [her] face" (Michell 2018). When Peter Hall offered her Cleopatra, she asked him if he really wanted "a menopausal dwarf" in the role (Michell 2018).

Dench's vaunting of her ostensible lack of beauty is important for two reasons. First, it corroborates public perception of her virtue within a patriarchal society: patriarchy values not only female modesty, but also women who actively downplay or deny their physical attractiveness. The furore when in 2002 Minnie Driver described Dench as "very small, round, [and] middle-aged", juxtaposed with widespread media assessments of her as actually "a beautiful woman" ("Dame Judi Dench: Then and Now" 2016), "a babe" and "beautiful" (Smyth 2017, in an article with the slug "dame-judi-dench-has-been-hot-all-her-life"), "exud[ing] sexiness, elegance, and class" (qtd Garnham 2016, p. 108) and colleagues' appreciation of the "sexy" actress, indicates that Dench's "Hollywood producer" took an anomalous view. Simultaneously, self-fashioning as ordinary or unattractive also augments Dench's dramatic authority: there is no danger of critics inferring that she has been cast for her appearance. Second, Dench's supposed ordinariness, and the fact that Dench remains highly visible as an older actress is valuable to the myth of British performance culture's uniquely inclusive attitude to age. In 2010, Vanessa Thorpe contrasted Dench's obviously ageing face with the cosmetic surgeries stereotypically associated with Hollywood, where "surgical artifice" and "a frozen face will keep you in the running for female lead roles". Thorpe claimed that Dench's professional success, alongside a small group of colleagues, constituted a "golden age" for older British actresses (Thorpe 2010). Thorpe's grouping of thirteen actresses as contemporaries when their ages range by twenty-three years elides the acting profession's ageism. Ageism 
disproportionately affects actresses, beginning, as Juliet Stevenson claims, at 35 (Stadlen 2015). Stevenson was part of the quintet of leading Shakespearean actresses, then aged 32-42, interviewed by Carol Chillington Rutter for her book Clamorous Voices (1988). By 2016, when the quintet was aged 60-70, only one, Harriet Walter, still regularly performed Shakespeare (Duncan 2016, pp. 224-5). The combination of ageism with the longevity gap between men and women (Sanders 2018) means that not only do actresses become under-employed sooner, they spend longer later lives under-employed. Dench, unlike Glenda Jackson and Harriet Walter, has continued to perform in Shakespeare without choosing or requiring the counter-strategy of cross-gender performance, apart from her brief gala appearance as "Hamlet the Dame" in Shakespeare Live!. While Dench is often invoked as an avatar of British theatrical distinctiveness, proving that "the only thing no other country has yet replicated are our theatre knights and dames" (Gore-Langton 2009), she resists this figleaf, recognising that Britain is "no better" than America (Tominey 2015). Simultaneously, however, Dench's vaunted "down-to-earth", "pleasingly normal" and "ordinary" persona should not be confused with an "ordinary" background: aside from being white and cisgender, Dench comes from an affluent middle-class background with theatrical connections, and was privately-educated as well as able to afford to train in a pre-grant era (Miller 2005, pp. 1-15). This is indeed "normal" for some of her peers: Vanessa Redgrave, Maggie Smith and Harriet Walter were all privately-educated though Helen Mirren was not. Redgrave was from a theatrical dynasty and a debutante (Queen's Gate 2019; Hadley 2015; Francis 2017; Anthony 2010).

\section{PRIVACY AND PERSONA: SilenCe AS StRATEGy}

One strategy which contributes to Dench's persona as a "consistent self", allowing the public to "trust who she is", draws on both her Quakerism and the strategies of her Shakespearean forebears: silence. Silence is key to the "retrospection" of Dench's late career (Elliott 2019, p. 20), as Dench deploys a revisionist silence on problematic personal experience, including those she previously discussed freely. Dench has never revealed the identity of her grandson's father, born after her unmarried daughter (the actress Finty Williams) concealed her pregnancy until shortly before the birth. Michael Williams, subsequently discussing his public support for "the sanctity of marriage", thought it "understandable that [Finty] was frightened. How could we, believing so strongly in marriage, accept an unmarried daughter?" (Middlehurst 1998). Dench offered no such discussion: her only comment in another interview, looking "bleak" and speaking "weakly" was "I don't want to talk about it" (Jardine 1997). Dench has never acknowledged her multi-decade rift with her actor brother Jeffery Dench, occasioned (the latter believed) by the mental illness of Jeffery's wife Betty, and Betty's feminism (Hardy 2007). When the Sunday Times published diptych interviews with the siblings, Jeffery also revealed that the 1970 death of RSC colleague Charles Thomas was a suicide preceded by the married actor falling in love with Dench (McFerran 2006). The Mail expanded on the story, with lurid corroboration from colleague Donald Sinden, citing "rumours that he and Judi were in a relationship [...] she was broken up completely" (Day 2007). Dench did not comment.

Most significantly, Dench has, in widowhood, remained silent on the challenges of her marriage. While early interviews for women's magazines lauded the "perfect pair['s]" marriage "founded on love and sweetened by romance" (Penlow 1983), after Williams's death, Finty's description of him as "unbelievably strict" clarified that the family's "dynamics", despite their "cultivated closeness", were "always more complex" than "either father, mother, or daughter has previously admitted". Williams was "controlling" and "a harsh critic" who "found [his wife's] Oscars difficult" (Wark 2004). Although during the 1990s, Dench was frank about her own temper and having thrown boiling tea at Williams (Honan 1992), she has never criticised Williams. The silence is at its most literal in the documentary Nothing Like A Dame, when discussion of the difficulties of acting with spouses - from Olivier's capriciousness and Robert Stephens's alcoholism leaving him "not a well man" - provokes a question about Williams. 
Dench stares out of the window, her right hand worrying at her throat, an eight-second silence stretching until Smith breaks it (Michell 2018).

Dench has euphemised her former frank avowals of an active sexuality. During the 1990s, she admitted to "a filthy mind" (Summers 1994), telling one interviewer that before marriage she "had a high old time, played the field [...] They all overlapped in my twenties. I was a fury, always in love with two at once" and experienced jealousy that made her "physically sick, it was like a cancer" (Honan 1992). Besides Dench's one long silence in the Nothing Like A Dame documentary, she carefully rebuffs the other actresses' discussion of sex. When Eileen Atkins responds to Dench's light-hearted remark that "perhaps we swung a bit early" (i.e. before the 1960s) with "We behaved pretty badly, actually, Judi", heavily implying their promiscuity, Dench markedly does not comment. When discussing regrets, she (eventually) says she would advise her younger self to "try not to be so susceptible to falling in love quite so often" (Michell 2018). Dench's silences allow her forcibly to control her image, historically minimising (her daughter, brother, and colleagues') impact on the impression of "virtue" and "moral authority" Pennington identifies as key to her persona. There are historical precedents for this: Ellen Terry's public elision of her children's illegitimacy allowed even Queen Victoria to watch mother and son onstage with lucrative impunity, while Madge Kendal's selective silence on her own family difficulties allowed her to self-fashion as "Mater Afflicta" (Duncan 2016, pp. 140; 27). While Dench publicly rejects the attribution of "niceness", "sweetness" or "national treasure status", she is careful not to expose elements of her private life that might threaten this: the impression of this as a conservative strategy is evident from the fact Dench says it is a practice she was taught by her husband. It is also perhaps unsurprising that Dench has become so reticent about her sexual past: a mild comment on the pleasures of her new relationship created press hysteria, some of it ribald and prurient, rather than supportive (Dougary 2017). Shakespeare has helped Dench navigate this shift, in an evolution away from the "tragic dowager" of the Countess of Rousillion (Wolf 2003) towards merrier widows such as Mistress Quickly, or the dynamic, voluble Paulina and Duchess of York.

\section{PERSONA AND AGEISM}

The overwhelming narratives surrounding Dench position her as an aspirational figure for the older woman: above all as someone who continues, willingly and enthusiastically, to work. Dench directs more vehemence at retiring than at ageing: as with discussion of her sexuality, this contradicts an earlier, rebarbative frankness. In 1994, Dench described her fear of becoming "kind of incontinent [...] and leaking in public", said she "mind[ed] passionately" about ageing because "Nothing's good about it" (Fallowell 1994). Now, however, Dench's angriest comments about age are in fact directed at ageism. In Nothing Like A Dame, she grows incensed about people's ageist assumptions ("if I can't do it, I'll tell you I can't do it") and the condescension of a paramedic who asked "What's our name [...] and have we got a carer?". Dench told him to "Fuck off, [...] I've just done eight weeks in The Winter's Tale at the Garrick Theatre' [...] I was so angry" (Michell 2018). Her rejection of the term "national treasure" originates, at least in part, from perceived connotations of ageism, relating it to "Alan Bennett and I [...] in some forgotten old cupboard" (Cochrane 2009).

Dench's diatribes about ageism position her at the culturally powerful intersection of two narratives. The first is the re-imagining of age via a social, rather than a medical, model. Where previously ageing was seen through a medical lens as "a time of increasing deficiency, based on a biological decline model", progressive views of ageing have for a generation argued that later-life negative experiences are based more on "environmental or experiential deficits" created by an ageist society, rather than by "intrinsic ageing phenomena" (Bennett \& Ahammer 1977, p. 8); successful ageing rests on socialised, subjective well-being (Kanning \& Schlicht 2008). Accordingly, Dench's problem is less age itself than negative experience at the hands of ageist individuals. Second, Dench's insistence on working and her fitness to work despite 
macular degeneration is (probably inadvertently) valuable to a conservative, late-capitalist agenda that seeks to cut welfare provision and thus requires older people to work for their sustenance and remain physically able.

Dench's expression of anger, however, represents a fascinating faultline between her self-construction and the attribution of personality undertaken by her audience and colleagues as "co-producers" of her persona. Dench insists she has become "more and more angry" (Cochrane 2009), and that "the older I become the angrier I become" (Pearce 2011).

Nevertheless, commentators rarely mention Dench's anger, describing her instead as "naughty" (see Nunn 2005, p. 68; Pigott-Smith 2005, p. 126; Dougary 2017). Semantically, the word connotes a combination of childish misdemeanour, ironised flirtatious or sexually provocative behaviour, and mischievous disobedience. Nunn certainly infantilises Dench in his description of her as "the naughty little sister" within a theatre company (Nunn 2005, p. 68), eliding her considerable artistic, financial, and hierarchical capital within that sphere. Describing Dench as "naughty" reduces her power and controls the implications of both her sexuality and her scatological language. Journalists emphasise her habit of embroidering obscenities on cushions as "naughty", foregrounding her swearing (still taboo for older women) as a "delight" as she parodies stereotypically quaint hobbies (HuffPost 2013), rather than associating her with the best-known persona of the swearing older woman in British culture: Catherine Tate's foulmouthed Nan (White 2014, pp. 164-5). Even the journalists most directly confronted by Dench's anger insist that she "wears [it] with twinkling pride" (Cochrane 2009): in Nothing Like A Dame, however, Dench's anger as she recounts her experience of ageism is anything but "twinkling" (Michell 2018).

\section{NATiONAL TREASURES AND NATIONAL PoEts}

Although Dench ostensibly rejects the persona of "national treasure", she self-constructs as a "national" actress, starring in recent galas for the subsidised theatre sector, in both literally and metaphorically "national" theatres: in National Theatre Live: 50 Years on Stage (2013) and Shakespeare Live! From the RSC (2016). She describes Shakespeare as Britain's "national poet" (Dunn 2017). Indeed, Dench's rejection of "F****** national treasure!" (Wise 2017) only reifies her status: other beloved British celebrities including Sir David Attenborough (Kendall 2009), Alan Bennett (Lawson 2014), and the late Sue Townsend and Victoria Wood all object[ed] vehemently to the term (Kellaway 2010; Barber 2014). Dench, unlike Alan Bennett, has accepted honours. Of the Nothing Like A Dame quartet, Dench was, in 1988, the first to be made a Dame, and in 2005 only the second actress in history to be made a Companion of Honour, the first being Dame Sybil Thorndike in 1970 (Billington 2001a, p. 327); Smith followed in 2014. Dench has also agreed to become patron of charities with a clear royal link, including Friends of Osborne House, the former royal residence of Queen Victoria.

Dench has also avoided overt political activity for most of her career. Despite recalling attending 1960s protests (Michell 2018), no images of Dench survive, and she did not join Sheila Hancock and Eileen Atkins (among many other colleagues) in protesting the 1976 detention of actors John Kani and Winston Nshona under apartheid laws (Anti-Apartheid Movement 2019). Her one known public act of protest was in opposition to the proposed 1989 redevelopment of the site of the Rose Theatre, Kingston (ITN 1989), a relatively uncontroversial cause relevant to her profession, respectively, and with cross-party appeal. Although Dench has been trustee or director of over 180 charities (McDonald 2005, p. 113), this has involved patronage rather than performance: while Dench and Harriet Walter are both patrons of feminist theatre company Clean Break, Harriet Walter ensured the casting of and performed alongside Clean Breaktrained actresses in the Donmar's Shakespeare Trilogy (Curtis 2016). Dench did perform alongside Ian McKellen and Ian Charleson in a gala opposing Section 28 (McKellen 1997), and undoubtedly has LGBT fans. Nevertheless, she has never become a gay icon like Maggie Smith, the inspiration for drag performances on Ru Paul's Drag Race ("RuPaul's Drag Race" 2014), and 
who openly acknowledged Kenneth Williams' "enormous influence" on her archly camp style (developed when they co-starred in Share My Lettuce, 1957) as early as 1965 (when homosexuality was still criminalised), describing her performance in Black Comedy as "a complete Kenneth" (Hartford 1998).

Dench's recent, more overt political engagements have mainly been with conservation campaigns, which have markedly cross-party appeal. As satirists recognise, to be "green" can be both centre-left and "marvellously New Tory": conservation is highly compatible with an Establishment affiliation, as individuals from organic farmer and Soil Association founder Lady Eve Balfour (1898-1990) to the Prince of Wales indicate (Mather \& Macartney-Snape 2007, p. 18). Dench's political affiliations have tended to reiterate her closeness to national institutions rather than ideologically inflect her persona. Dench's persona of "moral authority" also seems divorced from her political and charitable affiliations. Notably, more prominently politically active actors such as Vanessa Redgrave and Ian McKellen are not credited with this same "moral authority". This suggests two things: first, that "moral authority" in Dench's public persona is uncoupled from left-wing politics (despite the popular association between British theatre and the progressive Left). Second, Dench's distance from even mildly controversial political causes characteristically, Dench even refuses to "call [herself] a feminist at all" in favour of a supposed alternative that is in fact a watered-down gloss of its most basic concept: "I believe in women having a say" (Cochrane 2009) - reinforces this apolitical persona.

In terms of collaborations, Dench has tended towards long-term creative relationships with a small number of white male directors and producers with classical repertories; David Hare is a rare living playwright with whom she has repeatedly worked. Dench's performances for Hare have been in his least overtly political work, including Amy's View (1997) and The Breath of Life (2002). Dench's collaborative choices privilege continuity over departure, consolidating her powerbase. Some of these collaborators - Harvey Weinstein, Kevin Spacey, and Franco Zeffirelli - have recently been accused of sexual predation. Although Dench deemed allegations against Weinstein "horrifying", offering her "wholehearted support" to his accusers (Ruby 2017), she has remained loyal to Spacey. In September 2018, she still called Spacey "a most wonderful actor [...] and a good friend", and decried his removal from films ("Judi Dench defends "good friend" Kevin Spacey" 2018). Most recently, Dench declared that to forget or "negate" Spacey's work in particular would be "agony" and that "you cannot deny someone a talent" (Rouse 2019). Dench also worked with Franco Zeffirelli (1923-2019) from Hamlet (1960) to Tea With Mussolini (2009), but has never commented on the allegations he faced. The relative silence of most commentators could imply an acknowledgment of Dench's conflict when faced with allegations against friends from whose predation her status, age, and in the cases of Zeffirelli and Spacey, her gender shielded. Equally, however, Dench's audience's silence may reflect their investment in Dench's "saintly, sweet, and suburban" (Cochrane 2009) persona, and their parasocial desire to sustain it.

\section{PERSONAS AND SHAKESPEAREAN SUCCESSION}

Excluding a little-heard radio recording (Renaissance Theatre Company 1994), the one iconic older Shakespearean role for women that Dench has completely rejected is the Nurse in Romeo and Juliet, insisting: "The Nurse! F--- that for a game of marbles!" (Wolf 2003). Given her anxieties about ceasing to work or being 'forgotten', Dench perhaps dreads the role's careerfinishing place in the repertory. The Nurse has frequently been star actresses' final role, sometimes undertaken solely for financial reasons. Mary Anne Stirling (1815-1885) played the Nurse to both Ellen Terry and Mary Anderson from 1882-1884 (Taylor 2008; Marshall 2012, p. 387); in 1919, Terry, now visually and cognitively disabled, played the Nurse to Doris Keane's Juliet in her "last professional stage appearance" (Lennox 2015, p. 164-5). The Nurse was the last filmed Shakespeare role for Edna May Oliver (1936), Flora Robson (1954), Pat Heywood (1968), and (to date) Miriam Margoyles (1996). Another reason why Dench might reject the 
Nurse (Mistress Quickly is, after all, another bawdy older woman whom Dench played for broad laughs) is her proximity to Juliet, with connotations of theatrical succession. Historically, the same has been true of the Countess's relation to Helen in All's Well That Ends Well, epitomised by the RSC's 1982 production starring Dame Peggy Ashcroft and Harriet Walter. Predictably, critics in 2003 indulged "sentimental fantasy" that Claudie Blakley, Dench's Helena, would succeed her, positioning Dench as "a great performer passing the baton on to another actress of glorious promise” (Spencer 2003). Director Greg Doran invited comparison by disclosing that by "a strange coincidence" (unlikely), Blakley's "pilgrim" costume had been Dench's Lady Macbeth dress: "a neat handing on of tradition" (Doran 2005, p. 187). Blakley, however, has appeared twice in Shakespeare since 2003, and has never returned to the RSC. A second possibility, Alexandra Gilbreath was dubbed "the best Juliet since Judi Dench" by Michael Billington (2001b), who repeated the comparison (Billington 2003). Gilbreath co-starred with Dench in Merry Wives, appeared alongside her in Shakespeare Live! and was distinguished as the only younger actress invited to share the RSC's Dressing Room 102 (the star female dressing room) with Dench and fellow Dame Harriet Walter; Dame Helen Mirren, meanwhile, was in 105 with Catherine Tate, Pippa Nixon, and Anne Marie Duff ('Dressing Room List' 2016). Juliet Stevenson was in 2000 "dubbed 'the new Judi Dench"', having also "got big roles with the big companies" then "diversified to both small and big screens" ('The Actresses' 2000), but, as noted elsewhere, feels thwarted by ageism and no longer performs Shakespeare. Female performance genealogies in Shakespeare are more disparate and less documented than their male equivalents, which typically centre on the performance histories of tragic heroes. Female performers have no equivalent of the "red book" of Hamlet passed between the greatest Hamlet of successive generations: this book passed sequentially from Johnston Forbes-Robertson to Michael Redgrave, Peter O’Toole, Derek Jacobi, and Kenneth Branagh (Zenet Maher 1992, p. 226). Interestingly, Dearbhla Molloy's 2005 essay on Dench reprints a list of “Judi Dench's Rules of Shakespeare", supposedly dictated to Molloy, which Molloy claims "come down in a direct line from Ellen Terry" (I can find no evidence of this) and which Molloy had to "promise to pass on in [her] turn" (Molloy 2005, p. 92-3). Molloy, despite deeming Dench "impossible to emulate" (p. 98), is clearly self-fashioning as her successor. Although Russ McDonald described Dench as "well aware" of theatre's "apostolic succession" (he designated Samantha Bond Dench's successor), she has eschewed any anointing of a successor comparable to the Hamlet actors: in 2017, Kenneth Branagh presented Tom Hiddleston with Forbes-Robertson's edition of Hamlet (Armstrong \& Straker 2019, p. 2). Dench has, understandably, discouraged comparisons between herself and her daughter Finty Williams, who is also an actress, saying "I don't think it's kind" (Tominey 2015).

Much more than "niceness" constitutes Dench's artistic, political and moral personas in twenty-first-century British theatre. Nevertheless, Nothing Like A Dame certainly showcases Dench's amenability, compassion, and diplomacy. Maggie Smith highlights, then mimics "how Jude does it" when Dench patiently poses for stills while the others joke, and asks incredulously "when have we ever sat like this?" when seated beside her for a staged conversation, while Dench obediently assumes the position. When Smith ultimately dismisses the photographer, Dench looks deeply embarrassed. Dench's first sustained dialogue in the documentary establishes her as thoughtful and caring, explaining to the blind Joan Plowright that "I'm here, darling [...] not far away, just around the corner". In a debate about verse-speaking, when the pro-naturalistic Smith disagrees with the traditionalist Plowright, it is Dench who advocates for a "middle ground": "a way of using the poetry and being naturalistic" (Michell 2018). Dench typically takes evasive action to avoid outright conflict with directors: when asked to try something she finds difficult or objectionable, she announces "I'll get it up at home" (McDonald 2005, p. 123). This strategy serves three identifiable purposes for Dench: first, it enables her to retain artistic control of her performance without overtly defiant or "difficult" behaviour. Second, it locates Dench's persona in, and reiterates her connection to, the private domestic space over the more exposed rehearsal-room. Third, by keeping her interpretative process private, Dench also keeps it hidden: one reason Dench's technique 'never shows' even to 
colleagues might be that when preparing a role becomes most technically challenging for her, she prefers to do so in private.

Michell's 2018 documentary unquestionably presents Dench as the most successful of her peers. One of Dench's few marked moments of displeasure in the documentary came when describing Plowright's American agent, who sought for his client "a nice little cameo that Judi Dench hasn't got her paws on". "It's not rude at all", Smith countered, "it's true" (Michell 2018). The documentary consistently seats Dench at the centre of the group, or on the extreme left of frame, regarded as an authoritative or principal position on screen, given viewers' typical eyemovements (Arnheim 1974, pp. 34-5). Even when her pre-eminence is parodied or ironised, as when her conspicuously successful peers have to recite her name as a tongue-twisting vocal exercise, it is never really questioned. Above all, however, Shakespeare signals Dench's preeminence. Michell ends the documentary with Dench reciting Prospero's "Our revels now are ended" speech (IV.1.148-58) over images of herself and her co-stars as children. This ostensibly jarring choice (given Dench's rejection of retirement) becomes unexpectedly revealing. Dench's performance of The Tempest's leading character reaffirms her as the documentary's protagonist. It is also a definitive statement of Shakespeare's supreme importance to her persona and work, not only selecting her as Shakespeare's interpreter (out of a quartet of acclaimed Shakespearean actresses) but also, given the (however dubious) popular identification of Prospero with the playwright, as Shakespeare. The speech acknowledges Dench (and, given her delivery of it, sees Dench's self-acknowledgement) as "such stuff as dreams are made on": the dreams of a nation who simultaneously produce and consume Dench as "the jewel in the crown" of a supposed guarantee of British distinctiveness: "the only thing no other country has yet replicated are our theatre knights and dames" (Gore-Langton 2009). Dench's casting as Prospero confirms her status as a co-producer of this persona, since Prospero is not merely a "sprit" within his own play but the architect of his play's plot. If the Countess and subsequent merrier widows allowed Dench to achieve "autobiographical performance" (Elliott 2019, p. 19) and negotiate the persona of widowhood, this brief performance as Prospero signals that Dench is continuing to use Prospero to reiterate her status as foremost interpreter of our "national poet". Mindful of Michael Dobson's 2005 article on "the last Shakespearian role Dame Judi would ever play" (p. 163), I argue that Dench's Prospero should be read as a springboard not a coda. Dench's brief performance of Prospero, above all, signals her continuing ability to use Shakespeare to signal new directions for her career, with her late-career performance of yet another Shakespeare persona signaling departure rather than culmination. Her "revels" are not "ended".

\section{WORKS CITED}

'The Actresses' 2000, unattributed cutting, 1 January, in Shakespeare Birthplace Trust archive, GL5/83.6, Stratford-upon-Avon.

Anthony, A. 2010, 'Vanessa Redgrave', The Observer, 21 February, retrieved 14 September 2019, $<$ https://www.theguardian.com/theobserver/2010/feb/21/observer-profile-vanessaredgrave $>$.

Anti-Apartheid Movement 2019, 'Free All Political Prisoners', Forward to freedom: the history of the British Apartheid Movement, retrieved 1 October 2019, $<$ https://www.aamarchives.org/campaigns/political-prisoners.html>.

Appleyard, B. 2013, 'I need other people - for the jokes', Sunday Times, 27 October, retrieved 22 February 2019, <https://www.thetimes.co.uk/article/i-need-other-people-for-thejokes-dwzgpfflij8>.

Armstrong, E. \& Straker, D. 2019, 'Nomadic Hamlet 2.0', in R. Armstrong (ed.), Experimental Architecture, Routledge, Oxford, retrieved 1 July 2019, $<$ http://ualresearchonline.arts.ac.uk/14447/1/AAM\%20EA-EMA-ARMSTRONGNomadic-Hamlet-2.1-Final-Version.pdf>.

Arnheim, R. 1974, Art and Visual Perception, University of California Press, Los Angeles. 
Barber, R. 2014, 'National treasure?' Daily Mail, 25 December, retrieved 28 February 2019, $<$ https://www.dailymail.co.uk/tvshowbiz/article-2887115/National-treasure-oneJoanna-Lumley-s-got-gig-says-VICTORIA-WOOD.html\#ixzz46NWbVIke>.

Bennett, K. C. \& Ahammer, I. M. 1977, 'Toward a Social Deficit Model of Ageing', Australian Journal of Social Issues, vol. 12, no. 1, pp. 3-18.

Billington, M. 2001a, Stage and Screen Lives, Oxford University Press, Oxford.

- 2001b, 'Dark and thrilling Romeo at the Barbican', Guardian, 20 January, retrieved 27 May 2019, <https://www.theguardian.com/stage/2001/jan/20/theatre.artsfeatures >.

-2003, 'The Taming of the Shrew/The Tamer Tamed', Guardian, 11 April, retrieved 27 May 2019, < https://www.theguardian.com/stage/2003/apr/11/theatre.artsfeatures2>.

-2005, 'Please God, not retirement', Guardian, 12 September, in Shakespeare Birthplace Trust archive, GL5/83.6, Stratford-upon-Avon.

-2015, 'The Winter's Tale review', Guardian, 8 November, retrieved 13 Dec 2019, <

https://www.theguardian.com/culture/2015/nov/08/the-winters-tale-review-kenneth-branaghand-judi-dench-garrick>.

Bradshaw, P. 2019, 'Every Judi Dench film - ranked!', The Guardian, 18 April, retrieved 3 July 2019, <https://www.theguardian.com/film/2019/apr/18/every-judi-dench-filmranked>.

BSA 2018, 'Key findings', British Social Attitudes 36, retrieved 12 May 2019, $<$ http://www.bsa.natcen.ac.uk/latest-report/british-social-attitudes-36/keyfindings.aspx>.

Calkin, J. 2015, 'Portrait of a Lady', The Telegraph, 7 November, pp. 32-9.

Carlson, M. 2003, The Haunted Stage, University of Michigan Press, Ann Arbor.

Cochrane, K. 2009, 'Judi Dench: “Does nobody ever believe anything I do?"', The Guardian, 12 September, retrieved 1 September 2019,

$<$ https://www.theguardian.com/culture/2009/sep/12/judi-dench-interview>.

Connolly, B. 2005, 'Under His Oxter', in J. Miller (ed.), Darling Judi, Orion, London, pp. 170-7.

Curtis, N. 2016, 'Harriet Walter on the Donmar's all-female Shakespeare trilogy', Evening Standard, 14 September, retrieved 1 October 2019,

<https://www.standard.co.uk/go/london/theatre/harriet-walter-on-the-donmarsallfemale-shakespeare-trilogy-we-didnt-want-to-be-coy-about-addressinga3344456.html >.

'Dame Judi Dench causes havoc - Tracey Ullman's Show Episode 1 Preview', 2016, BBC on YouTube, 4 January, retrieved 30 June 2019, <https://www.youtube.com/watch?v=hNEfI6JnMJI>.

'Dame Judi Dench: Then And Now', 2016, Heart, 21 September, retrieved 10 September 2019, $<$ https://www.heart.co.uk/showbiz/beautiful-women-every-age/judi-dench/>.

Day, E. 2007, 'The tragic infatuation that haunts Dame Judi', Daily Mail, 13 January, retrieved 24 June $2019,<$ https://www.dailymail.co.uk/femail/article-428604/The-tragicinfatuation-haunts-Dame-Judi.html>.

Dobson, M. 2005, 'Writing about [Shakespearian] [sic] performance', Shakespeare Survey, vol. 58 , pp. 160-9.

Doran, G. 2005, 'Dench-olatry', in J. Miller (ed.), Darling Judi, Orion, London, pp. 181-9.

Dougary, G. 2017, 'I invented swearing!', Radio Times, 14 September, retrieved 3 May 2019, $<$ https://www.radiotimes.com/news/film/2017-09-14/i-invented-swearing-judidench-says-traceys-ullmans-impression-is-more-accurate-than-youd-think/>.

'Dressing Room List Level 1' 2016, Royal Shakespeare Company, 23 April, retrieved 29 May 2019, <http://i1.wp.com/www.indiefanboy.com/wpcontent/uploads/2016/04/rsc.jpg>.

Duncan, S. 2016, Shakespeare's Women and the Fin de Siècle, Oxford University Press, Oxford.

Dunn, C. 2017, 'Dame Judi Dench backs multi-million pound plan to build Shakespearean theatre in Merseyside', Liverpool Echo, 14 January, retrieved 1 October 2019, 
$<$ https://www.liverpoolecho.co.uk/news/liverpool-news/dame-judi-dench-backsmulti-12449945>.

Edmonds, R. 2003, 'Dame Judi in Unforgettable Style', Birmingham Post, 12 December, p. 14.

Elliott, R. 2019, 'Brilliant Disguises: Persona, Autobiography and the Magic of Retrospection in Bruce Springsteen's Late Career', Persona Studies, vol. 5, no. 1, pp. 17-32.

Eyre, R. 2005, 'Utterly Aware', in J. Miller (ed.), Darling Judi, Orion, London, pp. 34-44.

Fallowell, D. 1994, 'In fear of Jame Doodi', Observer, 26 June, in Shakespeare Birthplace Trust archive, GL5/83.6, Stratford-upon-Avon.

Francis, P. 2017, 'The Crown's Harriet Walter talks joys of being an older actress', Express, 15 October, retrieved 12 September 2019, <https://www.express.co.uk/lifestyle/life/865505/Harriet-Walter-TV-series-The-Crown-Clementine-Churchill-beingolder-actress $>$.

Garnham, B. 2016, A New Ethic Of "Older", Abingdon, Routledge.

Gore-Langton, R. 2009, untitled cutting, Daily Express, 27 December, in Shakespeare Birthplace Trust archive, GL5/83.6, Stratford-upon-Avon.

Guittard, L. 2005, 'Life Forces', in J. Miller (ed.), Darling Judi, Orion, London, pp. 147-69.

Hadley, T. 2015, 'Maggie Smith at 80', The Guardian, 23 January, retrieved 18 September 2019, $<$ https://www.theguardian.com/culture/2015/jan/23/maggie-smith-six-decadesactor-stage-screen>.

Hardy, R. 2007, 'Name of the dame', Mail Weekend Magazine, 27 January, in Shakespeare Birthplace Trust archive, GL5/83.6, Stratford-upon-Avon.

Hare, D. 2005, 'Re-inventing the Dame', in J. Miller (ed.), Darling Judi, Orion, London, pp. 178-80. Hartford, L. 1998, Desperately Funny: Kenneth Williams, BBC, 1 June 1998.

Honan, C. 1992, 'I was always in love with two men at the same time', Daily Mail, 21 January, in Shakespeare Birthplace Trust archive, GL5/83.6, Stratford-upon-Avon.

HuffPost 2013, 'Judi Dench's Secret Hobby', HuffPost Celebrity, 18 June, retrieved 4 October 2019, < https://www.huffpost.com/entry/judi-dench-secret-hobby n 3460379>.

ITN 1989, 'Rose theatre site development / actors join protests', ITN, 14 May, 17m 11s, retrieved 4 October 2019, <https://www.gettyimages.co.uk/detail/video/rose-theatresite-development-actors-join-protests-judi-news-footage/687303820>.

Jardine, C. 1997, 'My grandson was a big surprise', The Telegraph, 23 August, retrieved 23 February 2019, <https://www.telegraph.co.uk/culture/4710259/My-grandson-was-abig-surprise.html>.

'Judi Dench defends "good friend" Kevin Spacey and says she "can't approve" of him being cut from films' 2018, The Telegraph, 26 September, retrieved 28 February 2019, $<$ https://www.telegraph.co.uk/films/2018/09/26/judi-dench-defends-kevin-spaceysays-cant-approve-cut-films/>.

Kanning, M. \& Schlicht, W. 2008, 'A bio-psycho-social model of successful aging as shown through the variable "physical activity"', European Review of Aging and Physical Activity, vol. 5, pp. 79-87.

Kellaway, K. 2010, 'Sue Townsend: “I hate it when people call me a national treasure"', The Guardian, 1 August, retrieved 28 February 2019, $<$ https://www.theguardian.com/theobserver/2010/aug/01/sue-townsend-katekellaway>.

Kendal, M. 1884, The Drama, David Bogue, London.

Kendall, P. 2009, 'Sir David Attenborough', The Telegraph, 31 January, retrieved 28 February 2019, <https://www.telegraph.co.uk/news/4413130/Sir-David-Attenborough-Manwas-given-permission-to-exploit-the-natural-world-by-the-Bible.html>.

Krainitzki, E. 2014, 'Judi Dench's Age-inappropriateness and the Role of M: Challenging Normative Temporality', Journal of Ageing Studies, vol. 29, pp. 32-40.

Lawson, M. 2014, 'Alan Bennett at 80: everything but a national treasure', The Guardian, 9 May, retrieved 28 February 2019, <https://www.theguardian.com/stage/2014/may/09/alan-bennett-80-birthday-marklawson>. 
Leigh-Hunt, B. 2005, 'Early Days', in J. Miller (ed.), Darling Judi, Orion, London, pp. 20-6.

Lennox, P. 2015, 'How Designers Helped Juliet's Nurse Reclaim Her Bawdy', in P. Lennox and B. Mirabella (eds), Shakespeare and Costume, Bloomsbury, London, pp. 157-184.

Marshall, G. 2012, Shakespeare in the Nineteenth Century, Cambridge University Press, Cambridge.

Mather, V. \& Macartney-Snape, S. 2007, The Wicked Teenager: Social Stereotypes from the Telegraph Magazine, John Murray Press, London.

McDonald, R. 2005, Look to the Lady: Sarah Siddons, Ellen Terry, and Judi Dench on the Shakespearean Stage, University of Georgia Press, Athens.

McFerran, A. 2006, 'Judi Dench and her brother Jeffery', Sunday Times, 26 November, p. 5.

McKellen, I. 1997, 'Section 28/The Arts Lobby', Ian McKellen Official Homepage, retrieved 1 July 2019, < http://www.mckellen.com/activism/section28.htm>.

Michell, R. 2018 (dir.), Nothing Like A Dame, Field Day Films, Kew Media Group, 84 mins.

Middlehurst, L. 1998, 'Finty kept her pregnancy secret because of her fear of hurting us', Scottish Daily Mail, 28 February, in Shakespeare Birthplace Trust archive, GL5/83.6, Stratfordupon-Avon.

Miller, J. 2005, Darling Judi, Orion, London.

-2013, Judi Dench: With A Crack In Her Voice, Orion, London.

Molloy, D. 2005, 'Intuition on Instinct', in J. Miller (ed.), Darling Judi, Orion, London, pp. 87-98.

Moran, C. 2018, 'It was a week ago today...' The Times 26 May, retrieved 1 April 2019, $<$ https://www.thetimes.co.uk/article/it-was-a-week-ago-today-caitlin-moran-on-harrymeghan-and-the-royal-wedding-d0kqvmc7j>

Nightingale, B. 2005, 'Only Playing?' in J. Miller (ed.), Darling Judi, Orion, London, pp. 6-19.

Nunn, T. 2005, 'On A Roar', in J. Miller (ed.), Darling Judi, Orion, London, pp. 68-74.

Pearce, G. 2011, 'Dame Judi Dench', Daily Express, 16 June, retrieved 14 October 2019, $<$ https://www.express.co.uk/expressyourself/259189/Dame-Judi-Dench-I-ve-turnedinto-Mrs-Angry>.

Penlow, M. 1983, 'Oh yes, this is a fine romance!', Woman's Realm, 22 January, in Shakespeare Birthplace Trust archive, GL5/83.6, Stratford-upon-Avon.

Pennington, M. 2005, 'A Lass Unparallel'd', in J. Miller (ed.), Darling Judi, Orion, London, pp. 5867.

Pigott-Smith, T. 2005, 'Circling Like A Plane', in J. Miller (ed.), Darling Judi, Orion, London, pp. $125-136$.

Prince, K. 2013, 'Judi Dench', in R. Jackson (ed.), Great Shakespeareans, Bloomsbury, London, pp. 157-90.

Pua, P. 2018, 'Iron lady to old lady: the neutering of James Bond's M', Feminist Media Studies, vol. 18, no. 1, pp. 94-107.

Queen's Gate 2019, 'History', Queen's Gate, retrieved 24 September 2019, $<$ http://www.queensgate.org.uk/about-us/history/>.

Renaissance Theatre Company 1994, Romeo and Juliet, 2 January, BBC Radio 3.

Richardson, I. 2005, 'Arousing Admiration', in J. Miller (ed.), Darling Judi, Orion, London, pp. 2733.

Rouse, A. 2019, 'You can't deny someone a talent', Daily Mail, 25 June, retrieved 28 February 2019, <https://www.dailymail.co.uk/tvshowbiz/article-7176903/Dame-Judi-Dench-84discusses-battle-macular-degeneration-trauma-giving-driving.html>.

RSC, 2003, All's Well That Ends Well [annotated typescript] Shakespeare Birthplace Trust, RSC Collection, RSC/SM/2/2003/2, Stratford-upon-Avon.

Ruby, J. 2017, 'Judi Dench says sexual abuse allegations against long-time supporter Harvey Weinstein are "horrifying"', Standard, 9 October, retrieved 28 February 2019, $<$ https://www.standard.co.uk/showbiz/celebrity-news/judi-dench-says-sexual-abuseallegations-against-longtime-supporter-harvey-weinstein-are-horrifyinga3654441.html>.

'RuPaul's Drag Race: Snatch Game', 2014, Logo on YouTube, 9 September, retrieved 1 October 2019, <https://www.youtube.com/watch?v=d6ss9MhI3w4>. 
Sanders, S. 2018, 'National life tables, UK', Office for National Statistics, 25 September, retrieved 12 June 2019, $<$ https://www.ons.gov.uk/peoplepopulationandcommunity/birthsdeathsandmarriages /lifeexpectancies/bulletins/nationallifetablesunitedkingdom/2015to2017>.

Shakespeare, W. [1610] 1999, The Tempest, Bloomsbury, London.

- [1608] 1999, The Winter's Tale, Bloomsbury, London.

Sherrin, N. 2005, 'Like No Other', in J. Miller (ed.), Darling Judi, Orion, London, pp. 137-48.

Smyth, C. 2017, '25 Photos That Prove That Judi Dench Has Always Been A Babe', Buzzfeed, 21 September, retrieved 28 September 2019, <https://www.buzzfeed.com/cassiesmyth/woah-dame-judi-dench-has-been-hot-allher-life $>$.

Spencer, C. 2003, 'Dench makes every word count', The Telegraph, 12 December, p. 24.

Stadlen, M. 2015, 'Even Shakespeare is awful for middle-aged women', The Telegraph, 1 May, retrieved 12 March 2019, <https://www.telegraph.co.uk/culture/tvandradio/11576464/Even-Shakespeare-isawful-for-middle-aged-women.html>.

Summers, S. 1994, 'She is nothing like a dame', The Telegraph, 1 July, in Shakespeare Birthplace Trust archive, GL5/83.6, Stratford-upon-Avon.

Taylor, C. M. P. 2008, 'Stirling [née Hehl], Mary Anne [Fanny] (1813-1895)', Oxford DNB, retrieved 28 June 2019 <https://doi.org/10.1093/ref:odnb/26533>.

Thorpe, V. 2010, 'A golden age for Britain's acting grande dames', The Guardian, 31 December, retrieved 2 April 2019,

<https://www.theguardian.com/stage/theatreblog/2010/dec/31/female-actorsageing-golden-era>.

Tominey, C. 2015, 'Dame Judi Dench almost quit acting for motherhood', Express, 20 September, p. 21.

Wark, P. 2004, 'Heartbreak of Hearing Dad's Voice', The Times, 30 August, pp. 43-4.

Wells, S. 2005, 'Body Language', in J. Miller (ed.), Darling Judi, Orion, London, pp. 45-57.

White, R. 2014, 'Funny Old Girls: Representing Older Women in British Television Comedy', in I. Whelehan (ed.), Ageing, Popular Culture, and Contemporary Feminism, Palgrave Macmillan, Basingstoke, pp. 155-172.

Williams, M. 2015, 'The Best Exotic Graceful Ager: Dame Judi Dench and Older Female Celebrity', in D Jermyn \& S Holmes (eds), Women, Celebrity and Cultures of Ageing, Palgrave Macmillan, Basingstoke, pp. 146-62.

Wise, L. 2017, 'Judi Dench on playing Victoria again', Sunday Times, 27 August, Nexis UK.

Wolf, M. 2003, 'A widow of opportunity', The Telegraph, 30 November, p. 3.

YouGov 2018a, 'Queen Elizabeth II', YouGov, retrieved 8 September 2019, $<$ https://yougov.co.uk/topics/politics/explore/public figure/Queen Elizabeth II>.

-2018b, 'Judi Dench', YouGov, retrieved 14 October 2019, $<$ https://yougov.co.uk/topics/entertainment/explore/actor/Judi Dench>.

Zenet Maher, M. 1992, Modern Hamlets and Their Soliloquies, University of Iowa Press, Ann Arbor. 